\title{
FAKTOR-FAKTOR YANG MEMPENGARUHI INTENSITAS MARITAL CONFLICT
}

\author{
Yunita S. Syahrudin \\ HIMPSI Provinsi DKI Jakarta
}

\begin{abstract}
This study was done to examine factors that influence marital conflict intensity such as personality, social support, individual, and demographic variables like sex, marital age, income, education, divorce history of parents, dating history. 200 adults and have been married for at least two years who live in Jakarta were gathered as sample of his study. Data were obtained using modified version of The Revised Conflict Tactics Scale (CTS2), Big Five Inventory (BFI), The Social Provision Scale, and Multidimensional Measurement of Religiousness. Result of this study showed that there are significant effects of personality, social support, individual, and demographic variables on marital conflict intensity. Results of minor hypothesis testing which test significance of each dimensions of independent variables on marital conflict intensity showed that there are three significant regression coefficients, namely religiosity, marital age, conscientiousness personality type. Result of this study showed that variance proportion of marital conflict intensity which is explained by all independent variables is $42.8 \%$ and $57.2 \%$ residual.
\end{abstract}

Keyword: marital conflict, personality, social support, religiosity

\begin{abstract}
Abstrak
Penelitian ini dilakukan untuk mengetahui faktor-faktor yang mempengaruhi intensitas marital conflict seperti variabel kepribadian, dukungan sosial, dan individu serta variabel demografis yaitu jenis kelamin, usia menikah, pendapatan, pendidikan, riwayat perceraian orang tua, riwayat berpacaran. Sampel berjumlah 200 orang yang berusia dewasa dan sudah menikah selama dua tahun atau lebih, yang berdomisili di Jakarta. Dalam penelitian ini, penulis memodifikasi instrumen pengumpulan data, yaitu The Revised Conflict Tactics Scale (CTS2), Big Five Inventory (BFI), The Social Provision Scale, dan Multidimensional Measurement of Religiousness. Hasil penelitian menunjukkan bahwa ada pengaruh yang signifikan variabel kepribadian, dukungan sosial, religiusitas, dan faktor demografi terhadap intensitas marital conflict. Hasil uji hipotesis minor yang menguji signifikansi masing-masing dimensi dari independent variable terhadap intensitas marital conflict terdapat tiga koefisien regresi yang signifikan, diantaranya religiusitas, faktor demografi usia menikah, dan tipe kepribadian conscentiousness. Hasil penelitian ini menunjukkan proporsi varians dari intensitas marital conflict yang dijelaskan semua independent variable sebesar 42,8\% dan 57,2\% sisanya dipengaruhi oleh variabel lain di luar penelitian ini.
\end{abstract}

Kata kunci: marital conflict, kepribadian, dukungan sosial, religiusitas 


\section{PENDAHULUAN}

Menurut Sadarjoen (2005) marital conflict adalah kondisi disharmoni dalam pernikahan yang disebabkan sering terjadi perbedaan persepsi dan harapan. Disharmoni merupakan keadaan kurang selaras yang dialami suami dan isteri dalam rumah tangga. Persepsi yang berbeda terhadap berbagai persoalan dan fenomena rumah tangga, menjadikan situasi panas dan dapat memicu benturan emosi. Situasi rumah tangga menjadi makin kurang kondusif setelah menemukan kenyataan bahwa harapan yang dibangun selama ini dalam rumah tangga berbeda dengan kenyataan.

Konflik yang dialami dalam pernikahan merupakan sesuatu yang tidak bisa dihindari karena setiap orang mempunyai suasana hati berbeda yang cepat atau lambat memicu terjadinya ketegangan. Semakin dekat suatu hubungan maka semakin berpotensi untuk terjadinya konflik (Miller \& Pearlman, 2008). Logika ini terbalik dengan pemikiran bahwa makin dekat suatu relasi akan makin mendekatkan pada harmoni suatu hubungan antar individu.

Semua pernikahan mempunyai derajat konflik yang memiliki karakteristik tersendiri dan dapat bervariasi dari segi frekuensi, intensitas, isi, dan resolusi (Grych \& Fincham, 1990). Makin sering frekuensi konflik mengindikasikan derajat konflik makin tinggi, sebaliknya makin jarang frekuensi konflik mengindikasikan makin rendah derajat konflik. Intensitas konflik menggambarkan tingkat kekuatan suatu konflik, sehingga makin kuat intensitas konflik maka makin tinggi derajat konflik. Masih sedikit literatur yang mengemukakan tentang penyebab atau faktor yang mempengaruhi marital conflict di Indonesia, tetapi hal ini bisa kita lihat dari data perceraian yang sudah ada. Berdasarkan data Kementrian Agama, peristiwa cerai meningkat menjadi 14,6\% atau sebanyak 424.527 peristiwa pada pendataan terakhir (www.republika.co.id). Pada penelitian yang dilakukan oleh Allen dan Olson (2001) 42\% dari pasangan yang berkonflik memutuskan untuk bercerai. Penemuan ini mengisyaratkan bahwa konflik yang dialami dalam pernikahan bisa mendeteksi terjadinya perceraian.

Menurut Lambert dan Dollahite (2006) religiusitas dapat membantu pasangan mencegah masalah dalam hubungannya, menyelesaikan konflik, dan mengarahkan pada perdamaian. Dalam penelitian Ahmadi, dkk. (2008) juga ditemukan bahwa hubungan antara pasangan dengan Tuhan berpengaruh secara signifikan terhadap marital conflict karena dapat mengembangkan hubungan timbal balik dengan pasangan dan juga membantu pasangan untuk mendidik anak mereka.

Caughlin dan Vangelisti (2006) menyatakan bahwa faktor perbedaan individu, seperti konstruk kepribadian, yang memiliki hubungan dengan perilaku berkonflik. Dari kelima faktor yang ada dalam Big Five personality factor, neuroticsm yang berhubungan dengan kecemasan dan emosi negatif, berpengaruh secara positif terhadap konflik, seperti sikap negatif dan juga demand/withdraw. Tetapi, Bono, dkk. (2002) menemukan tidak hanya neuroticsm saja yang berpengaruh terhadap marital conflict bahkan extraversion dan conscientiousness juga berhubungan dengan konflik dalam suatu hubungan.

Menurut Lian dan Geok (2009), salah satu faktor yang dapat mempengaruhi konflik dalam pernikahan adalah dukungan sosial. Ketika tingkat dukungan sosial meningkat disertai tingkat stres yang menurun, maka konflik yang terjadi dalam keluarga bisa berkurang dalam satu tahun (Neff, 2012). 
Selain faktor diatas, ada beberapa faktor personal yang berhubungan dengan kemungkinan bercerai, yang juga dapat menimbulkan konflik dalam pernikahan, diantaranya berpacaran sebelum menikah, pernikahan pada usia dini, hamil diluar nikah, tidak memiliki anak, tinggal bersama anak tiri, riwayat perceraian orang tua, dan juga berdarah campuran (Papalia, Sterns, Feldman, \& Camp, 2002).

Norton dan Miller (Papalia dkk., 2002) berpendapat bahwa usia ketika menikah dan juga riwayat pendidikan yang menjadi faktor utama apakah pernikahan akan berlangsung lama. Usia untuk menikah yang memiliki peluang yang lebih besar untuk sukses dalam pernikahan adalah diatas dua puluh tahun akhir dan seterusnya.

Sejalan dengan penelitian tersebut, Amato dan Marriott mengatakan tidak hanya pasangan yang mempunyai karakteristik seperti berusia muda ketika menikah, tetapi juga memiliki orang tua yang bercerai dapat meningkatkan tingkat konflik pada pernikahan (dalam Lavner \& Bradburry, 2012). Penelitian yang dilakukan James dan Beattie (2012) bahkan menemukan berpacaran sebelum menikah juga memiliki hubungan yang negatif terhadap kebahagiaan dan komunikasi dalam pernikahan dan berhubungan positif dengan marital conflict.

Dilain hal, faktor personal penting lainnya yang juga dapat mempengaruhi konflik pada pernikahan adalah perbedaan jenis kelamin (Caughlin \& Vangelisti, 2006; Gottman \& Levenson, 1994). Perempuan lebih fokus pada hubungannya yang membuat cenderung lebih sering berkonflik (demand) dibandingkan laki-laki yang mana cenderung untuk menghindari konflik (withdraw).

Fincham (2003) menambahkan keadaan ekonomi juga memiliki hubungan dengan konflik dalam pernikahan. Pernyataan Fincham tersebut didukung oleh penelitian yang dilakukan Robila dan Krishnakumar (2005) yang menemukan keadaan ekonomi yang buruk berhubungan dengan meningkatnya marital conflict yang juga memiliki hubungan dengan rendahnya dukungan sosial dan depresi pada perempuan yang memiliki anak. Pap, Cummings, \& Morey (2009) juga menyatakan bahwa marital conflict yang berurusan dengan uang ditemukan lebih problematik, berulang, dan tidak terselesaikan dengan baik, daripada isu-isu yang lainnya.

Melihat dari berbagai macam faktor yang dapat mempengaruhi marital conflict, akan lebih baik jika kita juga mengetahui dampak apa yang ditimbulkan dari marital conflict tersebut. Berdasarkan penelitian yang dilakukan oleh Bloom dalam Sadarjoen (2005) terdapat konsekuensi negatif yang lain yang terjadi pada pasangan yang mengalami marital conflict, diantaranya yaitu peningkatan resiko psikopatologi, meningkatnya kecelakaan mobil yang berakibat fatal, meningkatnya kasus percobaan bunuh diri, meningkatnya perlakuan kasar antar pasangan, kehilangan daya tahan tubuh yang menyebabkan kerentanan dalam penyakit, kematian karena penyakit yang diderita dari ketegangan psikis, dan lain-lain.

Sependapat dengan hal tersebut, Fincham (2003) juga berpendapat bahwa orang yang mengalami konflik terus menerus dapat mengakibatkan penurunan kesehatan seperti penyakit kanker, penyakit jantung, dan penyakit kronis lainnya yang berhubungan dengan perubahan imunitas tubuh, fungsi kelenjar endokrin, dan fungsi jantung walaupun orang yang sudah menikah cenderung lebih sehat daripada orang yang tidak menikah. 
Beberapa dampak yang dapat ditimbulkan konflik yang terjadi dalam pernikahan merupakan dampak yang dapat merusak tidak hanya pada pasangan tetapi juga pada anak. Davies dan Cummings (1994) menyatakan bahwa marital conflict mempunyai efek yang merusak perkembangan anak terutama konflik yang disertai kekerasan, semakin tinggi intensitasnya maka semakin buruk dampaknya ada pada anak. Marital conflict merupakan faktor penentu yang lebih penting dari perceraian yang dialami orang tua tentang dampak negatif yang dialami anak (Caughlin \& Vangelisti, 2006).

Berdasarkan permasalahan di atas, peneliti sangat tertarik untuk meneliti faktor yang mempengaruhi intensitas marital conflict.

\section{Partisipan}

\section{METODE PENELITIAN}

Sampel dalam penelitian ini berjumlah 200 orang, yang ditentukan dengan teknik nonprobability sampling yaitu purposive sampling. Penelitian ini menggunakan pendekatan kuantitatif dengan analisis multiple regression.

\section{Prosedur}

Peneliti menentukan sampel berdasarkan individu yang sesuai dengan kriteria yang telah ditentukan oleh peneliti. Kriteria sampel dalam penelitian ini adalah pasangan suami istri yang berusia dewasa dan sudah menikah selama dua tahun atau lebih yang berdomisili di Jakarta, dan bersedia menjadi responden dalam penelitian ini. Sampel yang bersedia menjadi responden diminta untuk mengisi kuesioner. Kuesioner dapat diisi dan dikembalikan langsung kepada peneliti, tetapi ada sebagian kuesioner yang dikembalikan pada peneliti beberapa hari kemudian. Setelah pengembalian kuesioner, peneliti memberikan reward sebagai ucapan terima kasih karena telah berpartisipasi. Terkumpulnya jumlah sampel sebanyak 200 orang diperlukan waktu dua bulan lamanya.

Pengukuran Intensitas Marital Conflict. Skala yang digunakan adalah The Revised Conflict Tactics Scale (CTS2) yang dibuat oleh Straus, dkk (1996) yang meliputi dimensi negotiation (negosiasi), psychological aggresion (kekerasan psikologis), phsyical assault (kekerasan fisik), sexual coercion (pemaksaan hubungan seksual), injury (akibat dari konflik). The Revised Conflict Tactics Scale (CTS2) dalam penelitian ini menggunakan 32 item dan setelah dilakukan uji validitas tidak semua item valid sehingga harus di drop.

Dalam uji validitas konstruk skala intensitas marital conflict, peneliti menggunakan analisis CFA (Confirmatory Factor Analysis) yang dilakukan dengan model satu faktor. Selanjutnya peneliti melihat apakah signifikansi item tersebut mengukur faktor yang hendak diukur, sekaligus menentukan apakah item tersebut perlu didrop atau tidak. Maka dilakukan pengujian hipotesis nihil tentang koefisien muatan faktor dari item. Pengujiannya dilakukan dengan melihat nilai $t$ bagi setiap koefisien muatan faktor. Hasil pengujian terlihat bahwa seluruh item signifikan, yaitu memiliki nilai $t>1,96$. Tetapi, ada tiga item yaitu 1,2 , dan 11 yang memiliki koefisien bermuatan negatif, yang berarti item tersebut harus di drop. Selain itu, peneliti juga melihat apakah item-item tersebut saling berkorelasi, yang artinya item tersebut multidimensional dan ternyata tidak ada yang berkorelasi lebih dari tiga.

Langkah terakhir yaitu item-item intensitas marital conflict yang tidak didrop dihitung skor faktornya. Skor faktornya dihitung untuk menghindari estimasi bias dari kesalahan pengukuran. Jadi perhitungan skor faktor ini tidak menjumlahkan item-item 
variabel seperti pada umumnya, tetapi dihitung true score pada tiap skala. Skor faktor yang dianalisis adalah skor faktor yang bermuatan positif dan signifikan adapun rumus $\mathrm{T}$ Score. Setelah didapatkan skor faktor yang telah diubah menjadi $\mathrm{T}$ score, nilai baku inilah yang akan dianalisis dalam uji hipotesis korelasi dan regresi.

Tipe Kepribadian Big Five. Skala yang digunakan untuk mengukur tipe kepribadian adalah The Big Five Trait Inventory yang dibuat oleh dari Oliver P. John dan Sanjay Srivastava (1996). Skala kepribadian dalam penelitian ini terdiri atas 18 item yang harus diuji validitasnya.

Dalam uji validitas konstruk skala kepribadian, peneliti menggunakan analisis CFA (Confirmatory Factor Analysis) yang dilakukan dengan model satu faktor. Kepribadian dalam penelitian ini terbagi menjadi tiga dimensi, extraversion, consientiousness, dan neurotism. Hasil analisis CFA extraversion yang kemudian dimodifikasi terhadap model, di mana kesalahan pada beberapa item dibebaskan berkorelasi satu sama lainnya, maka diperoleh model fit dengan Chi-Square $=10.98, \mathrm{df}$ $=6, \mathrm{P}$-value $=0.08894, \mathrm{RMSEA}=0.065$. Sementara consientiousness diperoleh model fit dengan Chi-Square $=7.10, \mathrm{df}=6, \mathrm{P}$-value $=0.31150, \mathrm{RMSEA}=0.030$. Sedangkan neurotism diperoleh model fit dengan Chi-Square $=3.57, \mathrm{df}=1, \mathrm{P}$-value $=0.05895$, RMSEA $=0.114$. Dari hasil pengujian hipotesis nihil, item yang dimiliki dari empat dimensi kepribadian ada satu item yang harus di drop karena memiliki nilai koefisien bermuatan negatif yaitu item nomor 11. Dari hasil matriks korelasi antar kesalahan pengukuran juga terdapat item yang dikeluarkan yaitu item nomor 4 dan 7 . Dengan kata lain, item tersebut tidak diikutsertakan dalam analisis perhitungan faktor.

Dukungan Sosial. Skala dukungan sosial yang digunakan terdiri dari 24 item yang dimodifikasi dari skala The Social Provision Scale yang dikembangkan oleh Cutrona \& Russell (1987) dengan pengelompokan berdasarkan dimensi-dimensi attachment, social integration, reassurance of worth, reliable alliance, guidance, dan opportunity for nurturance.

Dalam uji validitas konstruk skala dukungan sosial, peneliti menggunakan analisis CFA (Confirmatory Factor Analysis) yang dilakukan dengan model satu faktor. Hasil analisis CFA dukungan sosial yang kemudian dimodifikasi terhadap model, di mana kesalahan pada beberapa item dibebaskan berkorelasi satu sama lainnya, maka diperoleh model fit dengan nilai Chi-Square $=177.26, \mathrm{df}=149, \mathrm{P}$-value $=0.05686$, RMSEA $=0.031$.

Dari hasil pengujian hipotesis nihil, item nomor 6 dan 7 dukungan sosial yang memiliki nilai $\mathrm{t}<1,96$ yang berarti harus didrop. Dari hasil matriks korelasi antar kesalahan pengukuran juga ada item yang dikeluarkan yaitu item nomor 5 dan 8 . Dengan demikian, item tersebut tidak diikutsertakan dalam analisis perhitungan faktor.

Religiusitas. Skala yang digunakan untuk mengukur religiusitas adalah skala yang berjudul Multidimensional Measurement of Religiousness, Spiritually For Use In Health yang dibuat oleh Fetzer (2003) yang disusun dalam 24 item berdasarkan enam dimensinya yaitu seberapa kuat individu penganut agama merasakan pengalaman beragama sehari-hari (dialy spiritual experience), mengekspresikan keagamaan sebagai sebuah nilai (value), meyakini ajaran agamanya (belief), maaf dan memaafkan (forgiveness), melakukan praktek beragama atau beribadah (private religious practice), dan menggunakan agama sebagai coping stres (religious/spiritual coping).

Dalam uji validitas konstruk skala religiusitas, peneliti menggunakan analisis CFA (Confirmatory Factor Analysis) yang dilakukan dengan model satu faktor. Hasil 
analisis CFA skala religiusitas kemudian dimodifikasi terhadap model, di mana kesalahan pada beberapa item dibebaskan berkorelasi satu sama lainnya, maka diperoleh model fit dengan nilai Chi-Square $=279.20, \mathrm{df}=246 \mathrm{P}$-value $=0.07159$, RMSEA $=0.026$.

Dari hasil pengujian hipotesis nihil, terdapat item yang memiliki nilai $\mathrm{t}<1,96$ yaitu item nomor 6 dan 17 dan item yang memiliki koefisien bermuatan negatif yaitu item nomor 13 . Dari hasil matrik korelasi antar kesalahan pengukuran tidak ada item yang dikeluarkan, artinya item yang tidak diikutsertakan dalam analisis perhitungan faktor adalah item nomor 6 , 13, dan 17.

\section{Analisa Statistik}

Untuk mengukur pengaruh kepribadian, dukungan sosial, dan religiusitas terhadap intensitas marital conflict, maka pengolahan data pada penelitian ini menggunakan analisis statistik Mutiple Regression Analysis (Analisis Regresi Berganda). Melalui regresi berganda ini dapat diperoleh nilai $\mathrm{R}$, yaitu koefisien korelasi berganda antara intensitas marital conflict dengan kepribadian, dukungan sosial, dan religiusitas. Besarnya variasi intensitas marital conflict yang disebabkan oleh faktor-faktor yang telah disebutkan tadi ditunjukkan oleh koefisien determinasi berganda atau $\mathrm{R}^{2} . \mathrm{R}^{2}$ merupakan proporsi varians dari intensitas marital conflict yang dijelaskan oleh kepribadian, dukungan sosial, dan religiusitas. Kemudian untuk menguji apakah pengaruh yang diberikan variabelvariabel independent signifikan terhadap dependent variable maka peneliti melakukan uji $t$.

\section{HASIL PENELITIAN}

\section{Karakteristik Partisipan}

Karakteristik Sampel Penelitian ( $\mathrm{N}=200)$

\section{Tabel 1}

Karakteristik Partisipan

\begin{tabular}{lcc}
\hline \multicolumn{1}{c}{ Karakteristik } & n & \% \\
\hline Jenis Kelamin & 102 & $51 \%$ \\
Laki-laki & 98 & $49 \%$ \\
Perempuan & & \\
& & \\
Usia Ketika Menikah & 80 & $40 \%$ \\
$16-23$ tahun & 104 & $52 \%$ \\
$24-31$ tahun & 16 & $8 \%$ \\
32 tahun ke atas & & \\
& & \\
Pendapatan per Bulan & 114 & $57 \%$ \\
$0-3,5$ juta & 65 & $32.5 \%$ \\
$3,5-7$ juta & 21 & $10.5 \%$ \\
7 juta keatas & & \\
Pendidikan Terakhir & 23 & $11.5 \%$ \\
SD & 23 & $11.5 \%$ \\
SMP & 101 & $50.5 \%$ \\
SMA & 8 & $4 \%$ \\
Diploma & &
\end{tabular}


S1

S2

Riwayat Perceraian Orang Tua

Bercerai

Tidak bercerai

Riwayat Berpacaran

Tidak berpacaran

Pacaran
36

9

$18 \%$

$4.5 \%$

14

186

$7 \%$

$93 \%$

\section{Analisa Regresi}

Dari hasil penelitian multiple regression diperoleh $R^{2}$ sebesar 0.449 atau $42.8 \%$ yang artinya $42.8 \%$ variasi dari intensitas marital conflict pada pasangan menikah di Jakarta yang dijelaskan oleh variasi seluruh independen variabel, sedangkan $58.2 \%$ sisanya dipengaruhi oleh variabel lain di luar penelitian ini.

Tabel 2

Analisis Anova

\begin{tabular}{llrrrrr}
\hline & Model & Sum of Squares & df & Mean Square & F & Sig. \\
\hline 1 & Regression & 8038.356 & 11 & 730.760 & 12.774 & .000 \\
Residual & 10754.662 & 188 & 57.206 & & \\
& Total & 18793.017 & 199 & & & \\
\hline
\end{tabular}

Dari Tabel 2 diketahui bahwa nilai signifikannya adalah 0.000 (sig $<0.05$ ), artinya hipotesis nihil, yang menyatakan tidak ada pengaruh yang signifikan seluruh IV terhadap intensitas marital conflict, ditolak. Maka dapat disimpulkan bahwa ada pengaruh yang signifikan dari tipe kepribadian (extraversion, concentiousness, neuroticsm), dukungan sosial, religiusitas, dan faktor demografi (jenis kelamin, usia ketika menikah, pendapatan, pendidikan, riwayat cerai orang tua, dan riwayat berpacaran) terhadap intensitas marital conflict.

Tabel 3

Koefisien Regresi Masing-masing IV

\begin{tabular}{|c|c|c|c|c|c|c|}
\hline & \multirow[b]{2}{*}{ Model } & \multicolumn{2}{|c|}{$\begin{array}{l}\text { Unstandardized } \\
\text { Coefficients }\end{array}$} & \multirow{2}{*}{$\begin{array}{c}\begin{array}{c}\text { Standardized } \\
\text { Coefficients }\end{array} \\
\text { Beta }\end{array}$} & \multirow[t]{2}{*}{$\mathbf{t}$} & \multirow[t]{2}{*}{ Sig. } \\
\hline & & B & Std. Error & & & \\
\hline \multirow[t]{9}{*}{1} & (Constant) & 81.583 & 7.402 & & 11.022 & .000 \\
\hline & Extraversion & -.048 & .073 & -.041 & -.657 & .512 \\
\hline & Conscientiousness & -.144 & .068 & -.126 & -2.122 & .035 \\
\hline & Neuroticism & .094 & .072 & .079 & 1.303 & .194 \\
\hline & Dukungan Sosial & .057 & .066 & .056 & .872 & .385 \\
\hline & Religiusitas & -.560 & .061 & -.561 & -9.133 & .000 \\
\hline & Jenis Kelamin & -.859 & 1.258 & -.044 & -.683 & 495 \\
\hline & Usia Menikah & -3.060 & .975 & -.194 & -3.139 & .002 \\
\hline & Pendapatan & 1.949 & 1.008 & .136 & 1.934 & .055 \\
\hline
\end{tabular}




\begin{tabular}{lrrrrr} 
Pendidikan & -.580 & .545 & -.078 & -1.064 & .289 \\
Riwayat Perceraian & .237 & 1.958 & .007 & .121 & .940 \\
$\begin{array}{l}\text { Orang Tua } \\
\text { Riwayat Pacaran }\end{array}$ & 3.008 & 1.768 & .099 & 1.701 & .091 \\
\hline
\end{tabular}

a. Dependent Variable: Intensitas Marital Conflict

Pada Tabel 3, signifikan atau tidaknya koefisien regresi yang dihasilkan dapat dilihat dari nilai sig pada kolom paling kanan. Apabila $\mathrm{p}<0.05$ maka koefisien regresi yang dihasilkan, signifikan pengaruhnya terhadap intensitas marital conflict. Berdasarkan data pada Tabel 3 di atas, nampak bahwa hanya koefisien religiusitas, usia saat menikah, dan tipe kepribadian conscientiousness yang berpengaruh secara signifikan terhadap intensitas marital conflict, sedangkan yang lainnya tidak signifikan.

\section{DISKUSI}

Berdasarkan uji hipotesis utama yang dilakukan dengan menggunakan uji multiple regression, maka penelitian ini dapat disimpulkan bahwa ada pengaruh yang signifikan dari tipe kepribadian, dukungan sosial, religiusitas, dan faktor demografi terhadap intensitas marital conflict. Kemudian hasil uji hipotesis minor yang menguji signifikansi setiap koefisien regresi terhadap dependen variabel, diperoleh tiga variabel yang signifikan berpengaruh terhadap intensitas marital conflict, yaitu variabel religiusitas, faktor demografi usia menikah, dan tipe kepribadian conscientiousness. Sedangkan sebanyak 8 (delapan) variabel lainnya tidak berpengaruh secara signifikan yaitu variabel extraversion, neuroticism, dukungan sosial, jenis kelamin, pendapatan, pendidikan, riwayat perceraian orang tua, dan riwayat pacaran.

Untuk variabel religiusitas terdapat pengaruh yang paling besar jika dilihat dari besaran koefisien regresi (atau beta) sebesar 0.561 terhadap intensitas marital conflict. Peneliti dapat menyimpulkan religiusitas lebih berpengaruh daripada faktor demografi usia menikah dan tipe kepribadian conscientiousness terhadap intensitas marital conflict pada pasangan yang sudah menikah di Jakarta. Religiusitas berpengaruh secara signifikan dengan arah negatif, artinya semakin tinggi religiusitas suatu pasangan menikah semakin kecil resiko mengalami marital conflict dan sebaliknya semakin rendah religiusitas suatu pasangan menikah semakin besar resiko mengalami marital conflict.

Tingkat intensitas marital conflict pada penelitian ini ada pada kategori sedang sebesar $47.5 \%$ dan mengarah pada kategori tinggi sebesar 30.0\% dari keseluruhan responden. Diperkirakan konflik yang terjadi tidak lagi pada tataran negosiasi, tetapi sudah memasuki kekerasan verbal yang mengarah pada kekerasan fisik. Hal ini menggambarkan bahwa intensitas marital conflict di Jakarta berada dalam kondisi waspada dan perlu ada tindak lanjut agar tidak mengarah pada perceraian. Jika hal ini dibiarkan tanpa ada tindakan, maka sudah pasti angka perceraian di Indonesia akan terus naik dari tahun ke tahun.

Selain itu, hasil penelitian ini menemukan bahwa religiusitas memberikan pengaruh terbesar dalam kaitannya dengan intensitas marital conflict, jika dibandingkan dengan variabel lainnya. Pengaruh yang dihasilkan juga memiliki arah yang negatif yang artinya semakin tinggi religiusitas maka semakin rendah intensitas marital conflict.

Interaksi pasangan dengan Tuhan-nya bisa berdampak secara signifikan kepada pasangan ketika konflik karena interaksi tersebut mengarahkan pasangan pada 
kedamaian. Tidak hanya itu, religiusitas yang ditemukan dari penelitian ini sepertinya dipandang sebagai pencegah konflik, resolusi konflik, atau sebagai rekonsiliasi seperti yang terdapat pada penelitian Lambert dan Dollahite (2006). Disini terlihat bahwa kebanyakan responden menjadikan agama sebagai coping ketika dilanda konflik, bukan menggunakan pendekatan fokus pada masalah yang sebenarnya sehingga masalah terus menerus ditekan dan tidak terselesaikan yang akan berdampak pada interaksi pasangan selanjutnya.

Untuk variabel dukungan sosial, pada penelelitian ini mayoritas responden ada pada tingkat $89.5 \%$ yang artinya responden didukung oleh orang-orang terdekatnya seperti keluarga dan sahabat. Tetapi hasil ini ternyata tidak mempengaruhi intensitas marital conflict secara signifikan. Berbeda dengan penelitian yang dilakukan oleh Lian dan Geok (2009) yang menyatakan bahwa keluarga dan sahabat terdekat mempengaruhi marital conflict.

Ada kemungkinan bahwa pasangan dengan intensitas marital conflict yang dihadapi dalam tingkatan sedang ini, mendapat dukungan dari orang terdekat namun tidak dalam pembahasan mengenai konflik yang dialami dalam rumah tangga. pembicaraan mengenai konflik dengan pasangan bisa jadi masih dianggap sebagai hal yang memalukan. Oleh karena konflik bisa mengarah pada perceraian, keluarga terutama orang tua, menganggap perceraian sebagai aib, maka banyak pasangan yang menghindari topik ini.

Dalam penelitian ini juga meneliti tentang faktor demografi yang memepengaruhi intensitas marital conflict diantaranya yaitu jenis kelamin, usia saat menikah, pendapatan, pendidikan, riwayat perceraian orang tua, dan riwayat berpacaran sebelum menikah. Dari keenam faktor demografi tersebut yang mempengaruhi intensitas marital conflict secara signifikan adalah usia ketika menikah. Mayoritas responden pada penelitian ini menikah pada rentangan usia 24-31 tahun. Rentangan usia ini ada pada tahapan dewasa awal, yang artinya mayoritas responden sudah matang secara fisik dan mental untuk memulai pernikahan. Seperti yang dikatan Norton dan Miller (dalam Papalia dkk., 2002) bahwa usia ketika menikah yang menjadi faktor utama apakah pernikahan akan berlangsung lama dengan peluang yang lebih besar untuk sukses dalam pernikahan terdapat pada usia diatas dua puluh tahun akhir dan seterusnya.

Usia menikah memberikan pengaruh secara negatif atau dapat dikatan bahwa semakin bertambah usia ketika menikah maka semakin rendah marital conflict yang dialami pasangan. Hasil ini sesuai dengan penelitian yang dilakukan Amato dan Marriott (dalam Lavner \& Bradburry, 2012) yang menemukan pasangan yang sudah menikah pada usia muda rentan akan konflik dalam pernikahannya.

Jenis kelamin pada penelitian ini tidak berpengaruh pada intensitas marital conflict yang dialami pasangan. mungkin hal ini disebabkan oleh jenis kelamin yang didominasi laki-laki, walau pun hanya berbeda dua suara dari perempuan, dimana lakilaki dianggap sebagai penghindar konflik. Sedangkan tingkat pendidikan meyoritas responden pada penelitian ini adalah tingkat SMA. Intensitas marital conflict yang sedang mungkin dikarenakan kurangnya kemampuan utnuk coping stress walaupun pendidikan dalam penelitian ini tidak berpengaruh secara signifikan. 
Pendapatan dari kebanyakan responden yang ada dalam kategori redah, mejadi pertanyaan mengapa variabel tersebut tidak mempengaruhi intensitas marital conflict. Hal ini mungkin karena sudah banyak responden yang memiliki pengaturan pengeluaran yang baik sehingga keadaan ekonomi tidak lagi menjadi masalah. Selain itu, pad apenelitian ini kebanyakan dari responden berpacaran sebelum menikah tetpai ternyata tidak terbukti mempengaruhi intensitas marital conflict. Pengalaman berpacaran di Indonesia dianggap sebagai tahap pengenalan calon pasangannya. Kemungkinan tidak berpengaruh karena budaya yang ada tidak mengizinkan tinggal bersama sebelum menikah, berbeda dengan budaya di luar negeri.

Faktor riwayat perceraian yang terjadi pada orang tua juga dianggap sebagai faktor yang mempengaruhi intensitas marital conflict karena biasanya anak menjadikan orang tua sebagai model. Frekuensi responden yang memiliki orang tua yang bercerai adalah rendah. Mungkin hal inilah yang menjadikan faktor perceraian tidak berpengaruh terhadap intensitas marital conflict.

Dalam penelitian ini tipe kepribadian yang diuji antara lain tipe kepribadian extraversion, tipe kepribadian conscientiousness, dan tipe kepribadian neuroticsm. Ternyata dalam penelitian ini diperoleh hanya tipe kepribadian conscientiousness yang memiliki pengaruh signifikan terhadap intensitas marital conflict dengan arah negatif yang berarti bahwa semakin tinggi tipe kepribadian conscientiousness, maka semakin rendah intensitas marital conflict. Tipe kepribadian conscientiousness dalam penelitian ini didominasi kategori rendah yang berarti kebanyakan dari responden sembrono, malas tidak terorganisir, terlambat, tidak punya tujuan, dan mudah menyerah (Pervin, Chervone, \& John, 2005; Feist \& Feist, 2010).

Penemuan ini cukup menarik, sebab kebanyakan penelitian mengaitkannya pada tipe kepribadian neuroticsm dengan sifat yang ditampilkan cenderung melibatkan emosi negatif seperti marah, cemas, atau depresi. Sifat yang ditampilkan oleh tipe kepribadian concentiousness pada kategori rendah adalah sifat sembrono, malas, dan tidak terorganisir. Sehingga tidak heran tipe kepribadian conscientiousness yang rendah ini mempengaruhi secara signifikan intensitas marital conflict yang ada pada kategori sedang. Hal ini dikarenakan adanya perbedaan tingkat tipe kepribadian conscientiousness pada pasangan seperti yang terdapat pada penelitian Bono, dkk. (2002).

Selain itu, tipe kepribadian extraversion yang tinggi pada penelitian ini ternyata tidak mempengaruhi intensitas marital conflict. Hal ini mungkin dikarenakan oleh mayoritas responden bersikap terbuka namun tidak pada pembahasan yang mengarah pada permasalahan dalam pernikahan. Masyarakat kita juga kebanyakan masih percaya bahwa tidak baik membicarakan urusan rumah tangga kepada orang lain.

Ada beberapa keterbatasan yang terdapat pada penelitian ini. Salah satunya adalah pada penelitian tentang pernikahan, banyak penelitian menjadikan marital conflict sebagai variabel independen. Terlebih lagi, mayoritas penelitian tersebut mengaitkan marital conflict dengan dampak yang ditimbulkan pada anak dan remaja seperti dampak terhadap penyesuaian diri anak, yang bisa dilihat dari penelitian Grych dan Fincham (1990) juga Davies dan Cummings (1994).

Keterbatasan selanjutnya adalah tidak semua variabel yang diteliti memberikan pengaruh yang signifikan pada intensitas marital conflict. Hasil pengujian hipotesis pengaruh seluruh independen variabel yakni kepribadian, dukungan sosial, religiusitas, 
dan faktor demografi pada penelitian ini menunjukkan bahwa ada pengaruh yang signifikan terhadap intensitas marital conflict pada orang yang sudah menikah di Jakarta. 


\section{DAFTAR PUSTAKA}

Ahmadi, K., Marzabadi, E. A., \& Ashrafi, S. M. N. (2008). The influence of religiosity on marital statisfaction. Journal of Social Sciences, 4 (2), 103-110. ISSN: 1549-3652.

Allen, W. D. \& Olson, D. H. (2001). Five types of african-american marriages. Journal of Marital \& Family Therapy 27, (3), 301-314.

Argyle, M. \& Furnham, A. (1983). Source of statisfication and conflicts in longterm relationship. Journal of Marriage and The Family, 10, 481-491.

D. (2009). Social psychology twelfth edition. Boston: Pearson Education, Inc.

Bono, J. E., Boles, T. L., Judge, T. A., \& Lauver, K. J., (2002). The role of personality in task and relationship conflict. Journal of Personality 70:3, 311-344.

Caughlin, J. P. \& Vangelisti, A. L. (2006). Conflict in dating and marital relationship. The SAGE Handbook of Conflict Communication. SAGE Publications, Inc. Doi: 10.4135/978-1-41297-617-6.n5

Cutrona, C. E. \& Russell, D. W., (1987). The provisions of social relationships and adaptation to stress. Advances in Personal Relationships, 1, 37-67. JAI Press Inc. ISBN: 0-89232-774-X.

Davies, P. T. \& Cummings, E. M. (1994). Marital conflict and child adjustment: An emotional security hypothesis. Psychological Bulletin, 116, 387-411.

DeLongis, A. \& Holtzman, S., (2005). Coping in context: The role of stress, social support, and personality in coping. Journal of Personality 73:6. Blackwell Publishing. DOI: 10.1111/j.1467-6494.2005.00361.x

Feist, J., Feist, G. J. (2009). Theories of personality $7^{\text {th }}$ ed. New York: McGraw Hill.

Fetzer, J. E., (2003). Multidimensional measurement of religiousness/spirituality for use in health research: A report of Fetzer Institute/National Institute on aging working group. Kalamazoo, MI: Fetzer Institute.

Fincham, F. D. (2003). Marital conflict: Correlates, structure, and context. Current directions in psychological science. New York: American Psychological Society.

Fincham, F. D., Beach, S. R. (1999). Conflict in marriage: Implications for working with couples. Annual Review Psychology, 50: 47-77

Gottman, J. M. \& Levenson, R. W., in Noller I. P. \& Fitzpatrick, M. A., (1988). The social psychophysiology of marriage. Perspectives on Marital Interactions. England: Multilingual Matters Ltd.

Grych, J. M. \& Finch, F. D. (1990). Marital conflict and children's adjustment: A cognitive - contextual framework. Psychological Bulletin, 108, 267 - 290.

James, S. L. \& Beattie, B. A., (2012). Reassessing the link between women's premartial cohabitation and marital quality. Soc Forces. doi: 10.1093/sf/sos126. 
John, O. P. \& Srivastava, S. (1999). The Big-Five trait taxonomy: History, measurement, and theoretical perspectives. Handbook of Personality: Theory and Research ( $2^{\text {nd }} e d$.). New York: Guilford.

Lambert, N. M. \& Dollahite, D. C., (2006). How religiousity helps couples prevent, resolve, and overcome marital conflict. Family Relations 55, (4), 439-449

Lavner, J. A. \& Bradbury, T. N. (2012). Why do even satisfied newlyweds eventually go on to divorce? Journal of Family Psychology, 26, 1-10. doi: 10.1037/a0025966

Levenson, R. W., Cartensen, L. L., Gottman, J. M., (1994). The influence of age and gender on affect, physiology, and their interrelations: A study of a long-term marriages. Journal of Personality and Social Psychology 62, (1), 56-68.

Lian, T. C. \& Geok, L. S. (2009). A study of marital conflict on measures of social support and mental health. Sunway Academic Journal 5, 97-110.

Lopez, J. L, Riggs, S. A., Pollard, S. E., Hook, J. N., (2011). Religious commitment, adult attachment, and marital adjustment in newly married couples. Journal of Family Psychology, 25, (2), 301-309. American Psychological Association. DOI: $10.1037 / \mathrm{a} 0022943$

Martin, G. C. \& Osborne, J. G. (1989). Psychology, adjustment, \& everyday living. New York: Prantice Hall.

Miller, R. S., Perlman, D. (2008). Intimate relationships, $5^{\text {th }}$ ed. Boston: McGraw Hill Higher Education.

Neff, L. A., (2012). Putting mariage in its context: The influence of external stress on early marital development, 179-203, United States: American Psychology Association.

Olson, D. H. \& Defrain, J. (2006). Marriages \& families: Intimacy, diversity, \& strengths, $5^{\text {th }}$ ed. United States: McGraw Hill.

Pap, L. M., Cummings, E. M., \& Goeke-Morey, M. C. (2009). For richer, for poorer: Money as a topic or marital conflict in the home. Family Relations, 58, 91-103.

Papalia, D. E., Sterns, H. L., Feldman, R. D. \& Camp, C. J. (2002). Adult development and aging (3rd ed). New York: McGraw-Hill.

Papalia, D. E., Olds, S. W., \& Feldman, R. D. (2007). Human development (10 th Ed). New York: McGraw-Hill

Pervin, L. A., John, O. P. (2001). Personality: theory and research. New York: John Wiley $\&$ Sons, Inc.

Robila, M. \& Krishnakumar, A. (2005). Effect of economic pressure on merital conflict in Romania. Journal of Family Psychology, 19, (2), 246-251. doi: 10.1037/08933200.19.2.246.

Sadarjoen, S. S., (2005). Konflik marital: Pemahaman konseptual, aktual, dan alternatif solusinya. Bandung: PT. Refika Aditama. 
Straus, M. A., Hamby, S. L., McCoy, S. B., \& Sugarman, D. B., (1996). The revised conflict tactics scales (CTS2): Development and preliminary psychometric data. Journal of Family Issues, 17, 283-316: Sage Publications, Inc. 